\title{
FORUM
}

\section{Designing for conservation of insects in the built environment}

\author{
MARYCAROLR. HUNTER ${ }^{1}$ and MARK D. HUNTER ${ }^{2} \quad{ }^{1}$ School of Natural Resources \\ and Environment, University of Michigan, Ann Arbor, MI, USA and ${ }^{2}$ Department of Ecology \& Evolutionary Biology and School of \\ Natural Resources and Environment, University of Michigan, Ann Arbor, MI, USA
}

\begin{abstract}
The conservation of insects is not a priority for most urban dwellers, yet can be accomplished in urban settings by the careful design of urban nature. Our goal is to foster cross-talk between practitioners of insect conservation biology who develop the knowledge base and professional design practitioners who are poised to apply this knowledge in designs and management plans for urban green space. The collaborative product promises a built environment that promotes human well-being and urban beauty while maximizing the potential for the conservation of insects.

2. There is precedence for collaboration between science and design communities to achieve conservation, and existing professional and civic organizations offer a structure to formalize and expand collaboration. Design professionals, particularly landscape architects, are trained to support insect conservation in the urban landscape through land planning and ecological site design.

3. Ecological site design is based in principles of sustainability and so must address the well being of humans and nature simultaneously. This powerful approach for insect conservation is illustrated in examples from around the world focusing on roadway-easement corridors, stormwater management areas, and greenroofs.

4. To improve insect conservation and its public support we offer recommendations, organized in response to cultural aspects of sustainability. Considerations include: a) social drivers for support of conservation practices, b) public perception of urban space, c) applying conservation biology principles in urban areas, and d) merging insect conservation goals with human cultural demands.
\end{abstract}

Key words. sustainable design, urban biodiversity, ecological site design, ecological aesthetics, insect habitat, place-attachment, landscape architecture, interdisciplinary collaboration, design professions, transportation corridors, stormwater management areas, greenroofs.

\section{Introduction}

It may be an anathema to the typical readers of this journal, but the sad fact is that most people don't like insects. Indeed, many otherwise reasonable biologists don't like insects either. We were reminded of this recently when an otherwise sane secondyear student smashed a neonate monarch caterpillar against a car, rather than have it crawling on her hand. Both car and hand

Correspondence: MaryCarol R. Hunter, School of Natural Resources and Environment, University of Michigan, Dana Building, 440 Church Street, Ann Arbor, MI 48109, USA. E-mail: mchunter@umich.edu

(C) 2008 The Authors

Journal compilation @ 2008 The Royal Entomological Society have been repaired; the monarch, alas, is beyond help. This episode followed shortly after an unfortunate incident with a group of three natural science students and an escaped laboratory cockroach. Our point is simply that insect conservation may be a hard sell, even among those who generally appreciate the environment and the value of what it provides.

But insects matter, everywhere (Kim, 1993). From wild lands to town centres, they provide vital ecosystem services as pollinators (Biesmeijer et al., 2006), decomposers (Wallace \& Merritt, 1980), enemies of pests (Perfecto \& Vandermeer, 2002), and prey in food webs (Hunter \& Price, 1992; Denno et al., 2002). They are the 'little things that run the world' (Wilson, 1987), 
diverse and abundant energy transducers that direct the flows of material and energy through food webs (Hunter, 2001; Speight et al., 2008). Many insects are also profoundly beautiful (DeVries, 1987). Unfortunately, some are also vectors of crop, livestock, and human disease (Gratz, 1999) and important pests in our production systems (Hunter, 1994, 2008). Perhaps their status as pests of human affairs has contributed to the largely negative public view of insects. Although the proportion of insect species that are pests is vanishingly small compared to the proportion that are not (Speight et al., 2008), insects generally fail to capture the public imagination as targets of conservation. A particular challenge is to facilitate the conservation of insect species in urban, suburban, and exurban areas where humans and insects encounter each other most frequently. Currently, about $50 \%$ of the world's population lives in cities and the percentage is expected to rise to $66 \%$ within about 20 years (McIntyre et al., 2001; Pickett \& Cadenasso, 2008). The rise of urban ecology as a field of study (Pickett et al., 2001; Faeth et al., 2005; Shochat et al., 2006; Cadenasso et al., 2007) provides both theoretical structure and intellectual motivation for an integrated approach to (insect) conservation in urban areas, emphasising the fundamental role of the social sciences and site design in the management of urban landscapes (Pickett \& Cadenasso, 2008). But cities must be managed primarily for the well-being of the people who live there, and ecological value is only one of many currencies important to urban dwellers.

Our goal is to foster cross-talk between practitioners of urban landscape design and insect conservation biology to promote human well-being and urban beauty while maximising the potential for the conservation of insects in urban environments. Here, we concentrate our discussion on urban environments in westernised nations with major cities where motorised transportation dominates and wild lands have been replaced by built or intensively managed ecosystems. We stress one further point at the outset - the design criteria that we describe are not simply prescriptions for maximising efforts in insect conservation. We approach this with an interest in people as well as in insects, with the assumption that effective conservation designs for urban areas will simply not persist unless people like them. Our criteria are as much about human welfare and aesthetic appeal as they are about insect species richness or threatened insect groups. In our view, insect conservation will be best served when biologists spend more time talking with professional design practitioners who are the dominant force in the design, installation, and management of urban green space.

\section{Collaboration between science and design communities to achieve conservation}

In the early 1980 s, insect conservation was focused on endangered species programmes, species-oriented research to determine what land or land type should be conserved, and landscape management plans to protect insect habitat (Pyle et al., 1981). Over the past 25 years, survey work on insect diversity and natural history has provided an ever stronger scientific basis for insect conservation planning and policy development. But the transfer of this information to those responsible for land development in the growing metropolis is not efficient (McGeoch, 2002). We suggest that entomologists can be key participants in bringing insect conservation to the built environment if a strong collaboration is forged with design professionals responsible for urban planning and, more importantly, for the actual design of development sites.

In creating designs for the built environment, landscape architects alter and create habitats. In each design, there is opportunity for conservation, stewardship, and restoration. Landscape architects choosing to use an ecological premise for design, turn to scientists or scientific documents to inform their decisions. There is already a precedent for collaboration among designers and scientists in support of conservation land planning efforts worldwide (Forman, 1995; Collinge, 1998). Professional design organisations that explicitly support the science-design collaboration occur worldwide and include, among others, the International Federation of Landscape Architects (2003), whose strategic plan supports professional development for the realisation of attractive, equitable and sustainable environments; the American Society of Landscape Architects (2006), that adopted an explicit code of environmental ethics in 2000; the European Foundation for Landscape Architecture (2008), whose objectives include effective action towards European landscape policies affecting loss of biodiversity by 2010; the Canadian Society of Landscape Architecture (http://csla.ca/site/index.php?q=en/node/5), that supports balance between our use and enjoyment of the land with the conservation and health of the environment; the Australian Institute of Landscape Architects (2008), that defines a professional as one who engages in research, planning, design and advises on the stewardship, conservation and sustainability in the development of the built environment and beyond, with responsibility to consider global climate change and population growth in their work. Similar goals are shared by the Chinese Society of Landscape Architecture (2008) and the Philippine Association of Landscape Architects (http:// www.pala.org.ph/history_definition.html). There is enormous potential for more effective insect conservation by using landscape architecture and entomology organisations to formalise connections between scientists and designers.

\section{Insect conservation in urban landscapes}

We assume that the readership of this journal is largely familiar with negative effects of urbanisation on insect diversity and we do not review them here. We should note, however, not everything about urbanisation is bad for insects. Cities can actually buffer and protect some species from extreme climatic events that may increase in frequency under global climate change (Shochat et al., 2004; Waite et al., 2007). Moreover, if exurban development continues at its current pace, urban areas will play an increasingly important role as sources of species that help to maintain biodiversity at the urban-rural interface (Carpaneto et al., 2005; Dunn et al., 2006). The idea that cities can serve as de facto sanctuaries for some species illustrates the need to consider urban design principles in conservation biology (Cook \& Faeth, 2006).

While insect conservation in the built environment is sometimes addressed directly, it is perhaps most easily achieved 
indirectly by site designs and management plans that aim to support more general goals such as high biodiversity or healthy ecosystem function. For example, urban green spaces have been shown to provide key resources for insect conservation (Eversham et al., 1996; McGeoch \& Chown, 1997; Ong, 2003; Loram et al., 2007). Positive effects of developed green space on insect diversity have been documented for private gardens (Gaston et al., 2005; Smith et al., 2006a,b), community gardens (Matteson et al., 2008); riparian buffers (Talley et al., 2007), public parks, zoos, and botanical gardens (Miller et al., 2004; Tommasi et al., 2004; Pinheiro et al., 2006; Hannon \& Hafernik, 2007), brownfields (Wood et al., 2001; Strauss \& Biedermann, 2006; Kozlov \& Zvereva, 2007), roadside vegetation (Helden \& Leather, 2004; Koivula et al., 2005; Saarinen et al., 2005), and golf courses (Frank \& Shrewsbury, 2004; Hodgkison et al., 2007; Audubon International, 2008). Even abandoned industrial areas, so-called brownfields, can serve as local reservoirs of terrestrial (Strauss \& Biedermann, 2006) and aquatic (Wood et al., 2001) insect diversity.

Where insect conservation is addressed directly, target species or their habitats are supported through one of two methods - land conservation and ecological site design. Land conservation protects valuable habitat from development whereas ecological site design modifies the built environment to meet the needs of target organisms or local ecosystems. Landscape architects and urban planners are trained to facilitate the first. Landscape architects are trained to create the second. Land conservation is often planned over a large geographical scale in order to address problems of habitat fragmentation, often with respect to the life-history needs of a single species or species group (Samways, 2005). The target is most often an endangered or beloved insect species. On a smaller scale, land conservation in urban areas often targets existing patches of quality habitat to support source populations and offer better habitat connectivity. At both scales, land conservation usually requires property purchase and may require legal protection to ensure that the land is not developed in the future. It may also require broad-based consensus and policy development. This type of conservation is not well met in urban areas owing to conflict with development goals and property ownership rights (Breuste, 2004). Consequently, in urban areas it is easier to support insect biodiversity through ecological site design. The size of the land parcel involved is relatively small, ranging from residential sites to city parks.

Guidelines for ecological site design provide directions for the creation of quality habitat for target species (e.g., see Shiro et al., 2001) and, where possible, for connectivity with existing patch-corridor networks. Since temporal change is a key player in how a landscape design looks (aesthetics) and functions ecologically over the long term, an ecological site design also requires a management plan. If the development project has an insect conservation component, the use of entomological expertise is critical during the development of site design and management plan in order to safeguard insect success over the long term. Landscape architects are predisposed to make ready use of information about temporal changes in insect requirements because they are trained to keep the impact of time on vegetation in sharp focus when developing a site design and its management plan. Entomological data on seasonal and cross generational changes in insect requirements (especially when multivoltine) can be readily accommodated and transformed to a design (for example, Talley et al., 2007) and management plan that creates and maintains critical habitat characteristics for the species of interest (Steytler \& Samways, 1995; Suh \& Samways, 2005; Hannon \& Hafernik, 2007).

\section{Examples of insect conservation through ecological site design}

Around the world, opportunities for ecological site design extend to urban open space, school properties, residential developments, home gardens, stormwater management areas, roadside corridors and most recently, greenroofs. Best-known examples come in response to imperilled insect pollinators. These designs generally attend to host plant provisioning and year round structural habitat requirements while offering an aesthetic experience that delights and engages the users. Public programmes support this approach in many countries. For example, the Buglife.org is a European centre for information that supports insect conservation through habitat management. The U.S. National Wildlife Federation has the Backyard Habitat Program (www.nwf.org/backyard/) that offers information on how to design residential and schoolyard spaces for biodiversity with a strong emphasis on beneficial insects.

Roadway-easement corridors are linear landscape elements, offering habitat strips that can be designed or managed to ameliorate disrupted ecosystem function or act as a corridor for passage between land-use types (Forman \& Alexander, 1998). In areas where motor transportation is significant, highway verges, roundabouts and cloverleaf greens provide abundant primary habitat for species capable of living outside wild-land conditions. This contribution to conservation can be substantial in highly urbanised regions. In Finland, for example, the total area of managed roadside habitat is now seven times greater than the area remaining in 'natural' grassland habitat (Saarinen et al., 2005). The potential of roadway lands for insect conservation has been recognised by a growing group of scientists in Britain (Free et al., 1975; Parr \& Way, 1988; Helden \& Leather, 2004), in Finland (Koivula et al., 2005; Valtonen et al., 2007), in France (Cheptou \& Avendano, 2006), and in South Africa (Whitmore et al., 2002). The potential for roadway lands to provide aesthetic value has long been recognised (Smardon \& Karp, 1992; Nassauer \& Larson, 2004; Raddi, 2004). The management of roadside aesthetics and protection of viewsheds has a long history of cultural support through historic preservation, and of economic support through tourism. It should be relatively easy to bring insect conservation goals to the planning table given the precedent for managing roadside habitat. Landscape architects have been critical players in context-sensitive highway habitat design (e.g., Schneider, 2003; Nassauer \& Larson, 2004). Collaboration among entomologists, highway planners, and roadside habitat designers could have a profound impact on insect conservation on roadside lands worldwide.

Stormwater management areas: Urban wetlands offer a particularly valuable opportunity for insect conservation (VillagranMella et al., 2006) in part because of declines in natural wetlands worldwide. Urban stormwater management and rainwater 
collection systems include devices familiar to everyone - swales, wet and dry detention ponds, and infiltration areas. The meeting of water and vegetation brings greater habitat diversity to urban areas and therefore, greater opportunity for insect diversity. Stormwater management designs prescribe a range of hydrological states and a plant species palette. If designed well and managed correctly, these systems can act as de facto wetlands, at least for some portion of the year. There is enormous potential to support worldwide conservation of beneficial insects and protect human settlements from detrimental insects through collaboration between entomologists and the design professionals (landscape architects and civil engineers) who create overland features of stormwater management systems. For some specific examples of how this can work, see Scher et al. (2004) and Scher and Thiery (2005).

Greenroofs are typically designed as low input stormwater management devices with an aesthetic appeal that supports the higher initial cost. Greenroofs can also be designed to support biodiversity by offering new habitat in urban areas, by providing better connectivity between existing habitats, and by serving as refuges in a fragmented landscape. This net benefit to insect conservation is documented for greenroofs in Switzerland (Brenneisen, 2006); in Britain (Jones, 2002; Kadas, 2006) and the USA (Coffman \& Davis, 2005). Lundholm (2006) proposed the use of natural ecosystems as templates for greenroof design based on the fact that greenroof conditions best support plants that come from shallow-substrate habitats such as the granite outcrop communities, limestone cliffs, and scree slopes. Lundholm (page 101, Table 1) supplies references on these and other plant communities characterised by shallow-soiled habitats from around the world. Designers can use the product of this research to select a rooftop plant palette that is relevant to place both ecologically and culturally. If designed with this premise, the greenroof will simultaneously support the conservation of local insect diversity and a place-specific plant community.

\section{Methods for achieving greater insect conservation in the metropolis}

While inroads have been made for insect conservation using land conservation and ecological site design, progress is not on par with conservation of more charismatic species such as birds. We believe that a stronger partnership between landscape architects, urban planners and entomologists can improve insect conservation and public support for insect conservation. The avenue to this success is discussed in the considerations and recommendations below. Realisation of these recommendations will be fuelled by an expanded interdisciplinary dialogue for the development of site design criteria informed by data on insect life history and natural community interactions. The dialogue will be most demanding for decisions on how to integrate human-use requirements into a functional conservation scheme. For this reasons, the considerations and recommendations are organised as a series of cultural considerations for ecological site design.

The ideal of supporting urban nature is not a sufficient condition for conservation. Personal, social and economic drivers such as aesthetic appeal, public safety and the protection of real estate value must be included in a sustainable conservation design (Nassauer, 1995, 1997; Kaplan et al., 1998). In the interest of supporting biodiversity in the metropolis, we address the interplay of four critical components of a well-grounded conservation plan: (i) social drivers that support conservation practices, (ii) public perception of outdoor spaces, (iii) applying conservation biology principles in urban areas, and (iv) merging conservation goals and cultural demands. Below, we consider each component in turn, making general observations and concrete suggestions for insect conservation plans where appropriate. We advocate integrating these considerations into any conservation programme ranging from simple changes in land management to the more complex creation of new habitat designs for the re-use of brownfields.

\section{Social drivers that support insect conservation practices}

It is at best naïve, and at worst unethical, to ignore public perception of the urban landscape in conservation management. There exists a rather myopic view that we can take the predictions from ecological theory (equilibrium theory of island biogeography, metapopulation dynamics, ecological genetics, and so on) and simply plug them into urban design without worrying about what the end result looks like. It turns out that people will not care for things they do not love (Gould, 1995). The success of any conservation plan requires long-term stewardship and this is most reliably founded on the desire of the community to care about the target of conservation - the insects or the habitat required to sustain them.

Consideration 1: People are more likely to support what they care about over the long term. Recommendation 1: Insect conservation plans should promote attachment and be well managed to ensure sustainability, that is, good ecological and aesthetic function over the long term. The expertise of entomologists, designers and social scientists are required to meet this challenge.

\section{Public perception of urban space and how to make people care}

It is often hard for biologists to remember that 'scruffy nature' is unappealing to many people - this being one reason why formal gardens have persisted for at least 4000 years (Jellicoe, 1995). We obviously want the diverse entomological fruits of entangled banks to flourish in all of their messy glory, but where and how those entangled banks are managed in urban areas can make the difference between sustainable or unsustainable conservation designs.

Research on public perception of the urban environment shows that people prefer green cities although the preferred format of 'green' varies from one individual to the next based on cultural experience, knowledge, sense of self and desire for security (Ulrich, 1986; Herzog \& Chernick, 2000; Ozguner \& Kendle, 2006; Jorgensen \& Tylecote, 2007; Matsuoka \& Kaplan, 2008). The preferred urban environment offers aesthetic appeal that engages and is satisfying (Jim \& Chen, 2006; Gobster et al., 
2007). But foremost, people want to see beauty in the area where they live, work and play, and those landscapes perceived as beautiful are more likely to be sustained through human effort (Nassauer, 1997). The sensory experiences provided by nature, even urban nature are perceived as restorative in some (but not all) cultures (Kaplan, 1995; Ito \& Kawarada, 2000; Hartig \& Staats, 2006). Experience of nature can also instill a sense of place (Kaplan \& Kaplan, 1989; Ryan, 2005; Jorgensen \& Tylecote, 2007). Since sense of place promotes sustainable behaviours (Parsons \& Daniel, 2002; Uzzell et al., 2002), an insect conservation plan that attends to the community's sense of beauty and sense of place will resonate in a way that establishes attachment and brings the essential long-term support.

Consideration 2: Ugly or unappreciated landscapes are not sustainable. Recommendation 2a: Create an ecologically functional site design that is aesthetically pleasing. This satisfaction leads to attachment. Recommendation $2 b$ : Since knowledge and familiarity have the capacity to shift cultural values, develop a programme to inform the site user about biology, ecology, and sustainability that underlies the design. In other words, reframe the users' reality.

Consideration 3: Communities differ in their environmental preferences, depending upon local history, climate, landform and native ecosystems. Recommendation 3: Characterise the landscape preferences that contribute to the community's sense of place and use these preferences in conjunction with insect habitat requirements to produce a site design or management plan that supports the insect conservation goal and is resonant with sense of place.

\section{Applying conservation biology principles in urban areas}

Cultural expectations may not be aligned with aesthetic impact of native plant communities (Breuste, 2004) and nature in the city may arrive with undesirable inquilines - invasive plants, outbreak insect species, garden pests, and vermin. It may be difficult to maintain the 'controlled beauty' people associate with garden design while allowing the urban ecosystem to function normally. We have an entomological colleague who lives in perennial despair of his neighbours who rake the leaves and woody debris from their wooded lot so that it 'looks pretty.' Sometimes, education can lead to a cultural shift in the notion of beauty (Gobster et al., 2007; Reason, 2007), although the evidence for that is patchy. What does produce a positive response in the face of messy nature is a positive experience with it. The presence of 'cues of care' is one approach that can initiate a shift in perception and acceptance (Nassauer, 1995). The classic example calls for the installation of mowed turf strips to frame a site that is without high appeal to the local community. It seems that people think better of a place when there is evidence that someone cares about it. When cultural norms evolve slowly, on-site art can be used in the short term to minimise people's negative reactions to unfamiliar landscapes (Hunter, 1999).

Consideration 4: Ecological requirements for insect conservation may result in a design/management plan that creates a less preferred or non-preferred landscape, especially over the short term. Recommendation 4a: The conservation design should include plans to help people embrace novelty and to reconnect with nature. Engaging methods of education (on site or Web-based) and interesting distraction (art, activity, cues to care) can increase attachment and positive aesthetic response. Recommendation 4b: Management of undesirable species can be handled through careful plant palette selection and sensitive engineering designs for stormwater management.

Consideration 5: We cannot fully predict the outcome of ecological designs. Recommendation 5: Installations should be monitored for the presence of desirable and undesirable species and evaluated for aesthetic appeal. As is the case for restoration projects, unexpected results are handled with adaptive management plans (Hunter, 2006).

\section{Merging conservation goals and cultural demands}

If developed lands are to serve insect conservation, a multidisciplinary approach is required to meet aesthetic values, ecological function, and economic reality. We suggest that landscape architects are poised to join entomologists to achieve this end for the following reasons. Their expertise supports the translation of insect conservation goals into reality. Their training is founded in ecology, art, civil engineering and stakeholder consensus. Typical work involves the development of site designs with a mind towards the larger spatial context in order to meet stormwater management regulations and location-specific zoning requirements for plantings, open space, slope, and transportation connectivity. Their design solutions are founded on sustainability principles, landscape aesthetics, human-use priorities, and cultural values, all of which must be addressed in a realised conservation design. In fact, landscape architects may already (and inadvertently) have the biggest daily impact on the conservation value of urban landscapes because their job is to define and control the landscape component of an everexpanding built environment.

Consideration 6: The profession of landscape architecture provides a nexus where the goals of conservation biologists and the aspirations of urban dwellers can meet. Recommendation 6: Insect conservation projects for urban areas should be developed by a collaborative team of qualified personnel trained to design simultaneously for the needs of insects and the preferences of people. Those trained in entomology, ecology and landscape architecture bring essential and unique skills to meet this demand.

Consideration 7: Research on the response of insects to stylised habitats typical of urban areas is minimal (except see Shiro et al., 2001; Collinge \& Palmer, 2002). Recommendation 7: Entomologists use the design expertise of landscape architects in collaborative research on how the spatial architecture of designed gardens, from naturalistic to highly stylised, influence insect biodiversity.

Consideration 8: Because of the nature of their work, landscape architects are inadvertently charged with creating the habitat of urban ecosystems. This responsibility should be well supported in the training of these professionals. Recommendation 8a: Within institutions of higher education, regular meetings of faculty and students in the disciplines of landscape architecture 
and conservation sciences would facilitate transfer of information about local opportunities for conservation work with insects and other groups. Recommendation $8 b$ : Landscape architecture programmes throughout the world train students to address insect conservation in studio projects that focus on foundation topics such as stormwater management, urban redevelopment and planting design. Studio projects are often pilot studies for local organisations, public and private. Studio outreach projects often influence realised designs and management recommendations and have the potential to make the value and methods for insect conservation known to community leaders.

\section{Final thoughts on insect conservation in urban environments}

Previous work has made the critical distinction between ecology 'in' cities, where habitats and organisms are studied within urban areas, and the ecology 'of' cities, where cities are seen as systems that interact in complex ways with the landscapes in which they are embedded (Grimm et al., 2000; Pickett et al., 2001). Here, we add ecology 'for' cities as a vital step in integration, because it recognises the importance of public desires, sense of place, and human designs in the management of urban space for biological value. In other words, if our designs and management plans are not, in large part, 'for' the urban dweller, those designs and plans will not be sustainable (Ryan, 2006). This is more than a restatement of the human ecosystem framework (Pickett et al., 2004; Pickett \& Cadenasso, 2006) in which feedbacks between human social systems and ecological function are modelled explicitly. Rather, ecology 'for' cities embraces the fundamental premise that cities should exist for the benefit of people and should be designed primarily with human well-being in mind. Of course, human well-being and environmental quality are tightly linked (Pickett \& Cadenasso, 2008), and this is where the opportunities for integration are most clear. By addressing both ecological function and the need for beauty in built environments, habitat fragments of varying sizes, designed with insect conservation in mind, can create linked systems along the urban-suburban-exurban gradient worldwide.

Across the globe, there are many places where survival is the goal and conservation is not. Even under these conditions, beneficial insect conservation practices that support immediate survival can be prescribed through interdisciplinary efforts. At the top of the list is conservation design aimed at protection of agricultural pollinators and other beneficial insects that support healthy agro-ecosystems or are able to keep human disease vectors in check. Elsewhere around the world, economic westernisation is growing cities at astonishing rates, leaving the protection of landscape at unprecedented risk. The type of support and intervention for insect conservation in this new remnant nature and at the ever-changing boundaries of the built environment brings another challenge for insect conservation. In these places, direct collaboration between entomologists and the design professions brings hope for the installation and maintenance of healthy ecosystems that support human well-being and beneficial insect conservation.

\section{References}

American Society of Landscape Architects (2006) ASLA Code of Environmental Ethics. www.asla.org/about/codeenv.htm

Audubon International. (2008) Audubon Cooperative Sanctuary Program for Golf Courses (ACSP). www.auduboninternational.org/programs/acss/ golf.htm

Australian Institute of Landscape Architects (2008) The Australian Landscape Charter. www.aila.org.au/charter/page04.htm

Biesmeijer, J.C., Roberts, S.P.M., Reemer, M., Ohlemuller, R., Edwards, M., Peeters, T., Schaffers, A.P., Potts, S.G., Kleukers, R., Thomas, C.D., Settele, J. \& Kunin, W.E. (2006) Parallel declines in pollinators and insect-pollinated plants in Britain and the Netherlands. Science, 313, 351-354.

Brenneisen, S. (2006) Space for urban wildlife: designing green roofs as habitats in Switzerland. Urban Habitats, 4, 27-36.

Breuste, J.H. (2004) Decision making, planning and design for the conservation of indigenous vegetation within urban development. Landscape and Urban Planning, 68, 439-452.

Cadenasso, M.L., Pickett, S.T.A. \& Schwarz, K. (2007) Spatial heterogeneity in urban ecosystems: reconceptualizing land cover and a framework for classification. Frontiers in Ecology and the Environment, 5, 80-88.

Carpaneto, G.M., Mazziotta, A. \& Piattella, E. (2005) Changes in food resources and conservation of scarab beetles: from sheep to dog dung in a green urban area of Rome (Coleoptera, Scarabaeoidea). Biological Conservation, 123, 547-556.

Cheptou, P.O. \& Avendano, L.G. (2006) Pollination processes and the Allee effect in highly fragmented populations: consequences for the mating system in urban environments. New Phytologist, 172, 774783.

Chinese Society of Landscape Architecture (2008) The Constitution of the Chinese Society of Landscape Architecture (CHSLA), Article 3. http://www.chsla.org.cn/english.htm

Coffman, R.R. \& Davis, G. (2005) Insect and avian fauna presence on the Ford assembly plant ecoroof. Proceedings of the 3rd North American Green Roof Conference: Greening Rooftops for Sustainable Communities, Washington DC. 4-6 May 2005. The Cardinal Group, Toronto, Ontario.

Collinge, S.K. (1998) Spatial arrangement of habitat patches and corridors: clues from ecological field experiments. Landscape and Urban Planning, 42, 157-168.

Collinge, S.K. \& Palmer, T.M. (2002) The influences of patch shape and boundary contrast on insect response to fragmentation in California grasslands. Landscape Ecology, 17, 647-656.

Cook, W.M. \& Faeth, S.H. (2006) Irrigation and land use drive ground arthropod community patterns in an urban desert. Environmental Entomology, 35, 1532-1540.

Denno, R.F., Gratton, C., Peterson, M.A., Langellotto, G.A., Finke, D.L. \& Huberty, A.F. (2002) Bottom-up forces mediate natural-enemy impact in a phytophagous insect community. Ecology, 83, 1443-1458.

DeVries, P.J. (1987) The Butterflies of Costa Rica and Their Natural History. Volume I: Papillionidae, Pieridae, Nymphalidae. Princeton University Press, Princeton, New Jersey.

Dunn, R.R., Gavin, M.C., Sanchez, M.C. \& Solomon, J.N. (2006) The pigeon paradox: dependence of global conservation on urban nature. Conservation Biology, 20, 1814-1816.

European Foundation for Landscape Architecture (2008) EFLA Strategic Plan 2007. www.efla.org/base/frames/centre.asp?LG=uk

Eversham, B.C., Roy, D.B. \& Telfer, M.G. (1996) Urban, industrial and other manmade sites as analogues of natural habitats for Carabidae. Annales Zoologici Fennici, 33, 149-156.

Faeth, S.H., Warren, P.S., Shochat, E. \& Marussich, W.A. (2005) Trophic dynamics in urban communities. Bioscience, 55, 399-407. 
Forman, R.T.T. (1995) Land Mosaics: The Ecology of Landscapes and Regions. Cambridge University Press, Cambridge, UK.

Forman, R.T.T. \& Alexander, L.E. (1998) Roads and their major ecological effects. Annual Review of Ecology and Systematics, 29, 207-231.

Frank, S.D. \& Shrewsbury, P.M. (2004) Effect of conservation strips on the abundance and distribution of natural enemies and predation of Agrotis ipsilon (Lepidoptera : Noctuidae) on golf course fairways. Environmental Entomology, 33, 1662-1672.

Free, J.B., Gennard, D., Stevenson, J.H. \& Williams, I.H. (1975) Beneficial insects present on a motorway verge. Biological Conservation, 8, 61-72.

Gaston, K.J., Smith, R.M., Thompson, K. \& Warren, P.H. (2005) Urban domestic gardens (II): experimental tests of methods for increasing biodiversity. Biodiversity and Conservation, 14, 395-413.

Gobster, P.H., Nassauer, J.I., Daniel, T.C. \& Fry, G. (2007) The shared landscape: what does aesthetics have to do with ecology? Landscape Ecology, 22, 959-972.

Gould, S.J. (1995) Adam's Navel and Other Essays. Penguin, Harmondsworth, UK.

Gratz, N.G. (1999) Emerging and resurging vector-borne diseases. Annual Review of Entomology, 44, 51-75.

Grimm, N.B., Grove, J.M., Pickett, S.T.A. \& Redman, C.L. (2000) Integrated approaches to long-term studies of urban ecological systems. Bioscience, 50, 571-584.

Hannon, E.R. \& Hafernik, J.E. (2007) Reintroduction of the rare damselfly Ischnura gemina (Odonata : Coenagrionidae) into an urban California park. Journal of Insect Conservation, 11, 141-149.

Hartig, T. \& Staats, H. (2006) The need for psychological restoration as a determinant of environmental preferences. Journal of Environmental Psychology, 26, 215-226.

Helden, A.J. \& Leather, S.R. (2004) Biodiversity on urban roundabouts - Hemiptera, management and the species-area relationship. Basic and Applied Ecology, 5, 367-377.

Herzog, T.R. \& Chernick, K.K. (2000) Tranquility and danger in urban and natural settings. Journal of Environmental Psychology, 20, 29-39.

Hodgkison, S., Hero, J.M. \& Warnken, J. (2007) The efficacy of smallscale conservation efforts, as assessed on Australian golf courses. Biological Conservation, 135, 576-586.

Hunter, M.C. (1999) Evolution of an Ecological Aesthetic and Its Application to an Environmentally Progressive Community on Dewees Island. M.L.A., University of Georgia, Athens, Georgia.

Hunter, M.C. (2006) Ecological community restoration. Landscape Architectural Graphics Standards; Professional Edition (ed. by L.J. Hopper), pp. 792-798. John Wiley \& Sons, New York.

Hunter, M.D. (1994) The search for pattern in pest outbreaks. Individuals, Populations and Patterns in Ecology (ed. by S.R. Leather, A.D. Watt, N.A.C. Kidd \& N.J. Mills), pp. 443-448. Intercept, Andover, UK.

Hunter, M.D. (2001) Insect population dynamics meets ecosystem ecology: effects of herbivory on soil nutrient dynamics. Agricultural and Forest Entomology, 3, 77-84.

Hunter, M.D. (2008) Root herbivory in forest ecosystems. Root Feeders, an Ecosystem Perspective (ed. by P. Murray, S. Johnson \& G.J. Masters). CAB Biosciences, Oxford, UK.

Hunter, M.D. \& Price, P.W. (1992) Playing chutes and ladders: heterogeneity and the relative roles of bottom-up and top-down forces in natural communities. Ecology, 73, 724-732.

International Federation of Landscape Architects (2003) Proposed IFLA Strategic Plan. www.iflaonline.org/resources/policy/pdf/ifla_ strategic_plan.pdf

Ito, T. \& Kawarada, M. (2000) Environmentalism in Japanese gardens. Environmentalism in Landscape Architecture (ed. by M. Conan), pp. 245-268. Dumbarton Oaks Research Library, Washington, DC.
Jellicoe, G.A. (1995) The Landscape of Man: Shaping the Environment from Prehistory to the Present Day, 3rd edn. Thames \& Hudson, London.

Jim, C.Y. \& Chen, W.Y. (2006) Perception and attitude of residents toward urban green spaces in Guangzhou (China). Environmental Management, 38, 338-349.

Jones, R.A. (2002) Tecticolous invertebrates: A preliminary investigation of the invertebrate fauna on green roofs in urban London. English Nature, Peterborough, London. Available from URL: www.livingroofs.org/NewFiles/Tecticolous\%20Insects.pdf

Jorgensen, A. \& Tylecote, M. (2007) Ambivalent landscapes - wilderness in the urban interstices. Landscape Research, 32, 443-462.

Kadas, G. (2006) Rare invertebrates colonizing green roofs in London. Urban Habitats, 4, 66-86. Available from UR1: http://www.urbanhabitats.org/v04n01/invertebrates_full.html

Kaplan, R. \& Kaplan, S. (1989) The Experience of Nature: A Psychological Perspective. Cambridge University Press, New York.

Kaplan, R., Kaplan, S. \& Ryan, R.L. (1998) With People in Mind: Design and Management of Everyday Nature. Island Press, Washington, DC.

Kaplan, S. (1995) The restorative benefits of nature: toward an integrative framework. Journal of Environmental Psychology, 15, 169-182.

Kim, K.C. (1993) Biodiversity, conservation and inventory: why insects matter. Biodiversity and Conservation, 2, 191-214.

Koivula, M.J., Kotze, D.J. \& Salokannel, J. (2005) Beetles (Coleoptera) in central reservations of three highway roads around the city of Helsinki, Finland. Annales Zoologici Fennici, 42, 615-626.

Kozlov, M.V. \& Zvereva, E.L. (2007) Industrial barrens: extreme habitats created by non-ferrous metallurgy. Reviews in Environmental Science and Biotechnology, 6, 231-259.

Loram, A., Tratalos, J., Warren, P.H. \& Gaston, K.J. (2007) Urban domestic gardens $(\mathrm{X})$ : the extent and structure of the resource in five major cities. Landscape Ecology, 22, 601-615.

Lundholm, J.T. (2006) Green roofs and facades: a habitat template approach. Urban Habitats, 4, 87-101.

Matsuoka, R.H. \& Kaplan, R. (2008) People's needs in the urban landscape: analysis of landscape and urban planning contributions. Landscape and Urban Planning, 84, 7-19.

Matteson, K.C., Ascher, J.S. \& Langellotto, G.A. (2008) Bee richness and abundance in New York city urban gardens. Annals of the Entomological Society of America, 101, 140-150.

McGeoch, M.A. (2002) Insect conservation in South Africa: an overview. African Entomology, 10, 1-10.

McGeoch, M.A. \& Chown, S.L. (1997) Impact of urbanization on a gallinhabiting Lepidoptera assemblage: the importance of reserves in urban areas. Biodiversity and Conservation, 6, 979-993.

McIntyre, N.E., Rango, J., Fagan, W.F. \& Faeth, S.H. (2001) Ground arthropod community structure in a heterogeneous urban environment. Landscape and Urban Planning, 52, 257-274.

Miller, B., Conway, W., Reading, R.P., Wemmer, C., Wildt, D., Kleiman, D., Monfort, S., Rabinowitz, A., Armstrong, B. \& Hutchins, M. (2004) Evaluating the conservation mission of zoos, aquariums, botanical gardens, and natural history museums. Conservation Biology, 18, 86-93.

Nassauer, J.I. (1995) Messy ecosystems, orderly frames. Landscape Journal, 14, 161-170.

Nassauer, J.I., ed. (1997) Placing Nature: Culture in Landscape Ecology. Island Press, Washington, DC.

Nassauer, J.I. \& Larson, D. (2004) Aesthetic initiative measurement system - a means to achieve context-sensitive design. Highway Facility Design 2004 (ed. by N.R. Council), pp. 88-96. Transportation Research Board National Research Council, Washington, DC.

Ong, B.L. (2003) Green plot ratio: an ecological measure for architecture and urban planning. Landscape and Urban Planning, 63, 197-211. 
Ozguner, H. \& Kendle, A.D. (2006) Public attitudes towards naturalistic versus designed landscapes in the city of Sheffield (UK). Landscape and Urban Planning, 74, 139-157.

Parr, T.W. \& Way, J.M. (1988) Management of roadside vegetation: the long-term effects of cutting. Journal of Applied Ecology, 25, 1073-1087.

Parsons, R. \& Daniel, T.C. (2002) Good looking: in defense of scenic landscape aesthetics. Landscape and Urban Planning, 60, 43-56.

Perfecto, I. \& Vandermeer, J. (2002) Quality of agroecological matrix in a tropical montane landscape: ants in coffee plantations in southern Mexico. Conservation Biology, 16, 174-182.

Pickett, S.T.A. \& Cadenasso, M.L. (2006) Advancing urban ecological studies: frameworks, concepts, and results from the Baltimore Ecosystem Study. Austral Ecology, 31, 114-125.

Pickett, S.T.A. \& Cadenasso, M.L. (2008) Linking ecological and built components of urban mosaics: an open cycle of ecological design. Journal of Ecology, 96, 8-12.

Pickett, S.T.A., Cadenasso, M.L. \& Grove, J.M. (2004) Resilient cities: meaning, models, and metaphor for integrating the ecological socio-economic, and planning realms. Landscape and Urban Planning, 69, 369-384.

Pickett, S.T.A., Cadenasso, M.L., Grove, J.M., Nilon, C.H., Pouyat, R.V., Zipperer, W.C. \& Costanza, R. (2001) Urban ecological systems: linking terrestrial ecological, physical, and socioeconomic components of metropolitan areas. Annual Review of Ecology and Systematics, 32, 127-157.

Pinheiro, M.H.O., Neto, L. \& Monteiro, R. (2006) Urban areas and isolated remnants of natural habitats: an action proposal for botanical gardens. Biodiversity and Conservation, 15, 2747-2764.

Pyle, R., Bentzien, M. \& Opler, P. (1981) Insect conservation. Annual Review of Entomology, 26, 233-258.

Raddi, A.G. (2004) Blending biodiversity, bloom and bio-aesthetics: highway hues. Wastelands News, 20(1) 20-27.

Reason, P. (2007) Education for ecology - science, aesthetics, spirit and ceremony. Management Learning, 38, 27-44.

Ryan, R.L. (2005) Exploring the effects of environmental experience on attachment to urban natural areas. Environment and Behavior, 37, $3-42$.

Ryan, R.L. (2006) The role of place attachment in sustaining urban parks. The Humane Metropolis: People and Nature in the 21st-Century City (ed. by R.H. Platt), pp. 61-74. University of Massachusetts, Amherst, Massachusetts.

Saarinen, K., Valtonen, A., Jantunen, J. \& Saarnio, S. (2005) Butterflies and diurnal moths along road verges: does road type affect diversity and abundance? Biological Conservation, 123, 403-412.

Samways, M.J. (2005) Insect Diversity Conservation. Cambridge University Press, Cambridge, UK.

Scher, O., Chavaren, P., Despreaux, M. \& Thiery, A. (2004) Highway stormwater detention ponds as biodiversity islands? Archives Des Sciences, 57, 121-130.

Scher, O. \& Thiery, A. (2005) Odonata, amphibia and environmental characteristics in motorway stormwater retention ponds (Southern France). Hydrobiologia, 551, 237-251.

Schneider, K. (2003) The Paris-Lexington Road: Community-based Planning and Context Sensitive Highway Design. Island Press, Washington, DC.

Shiro, N., Matsumoto, K., Atsishi, N., Shinebu, Y. \& Hiroyuki, Y. (2001) Relationship between shape-architecture of Miscanthus sacchariflorus community and biodiversity of the Thysanopteran insects of banks within urban area. Journal of the Japanese Institute of Landscape Architecture, 64(5), 601-606.

Shochat, E., Stefanov, W.L., Whitehouse, M.E.A. \& Faeth, S.H. (2004) Urbanization and spider diversity: influences of human modification of habitat structure and productivity. Ecological Applications, 14, $268-280$.
Shochat, E., Warren, P.S. \& Faeth, S.H. (2006) Future directions in urban ecology. Trends in Ecology \& Evolution, 21, 661-662.

Smardon, R.C.K. \& Karp, J.P. (1992) The Legal Landscape: Guidelines for Regulating Environmental and Aesthetic Quality. Van Nostrand Reinhold, New York.

Smith, R.M., Gaston, K.J., Warren, P.H. \& Thompson, K. (2006a) Urban domestic gardens (VIII): environmental correlates of invertebrate abundance. Biodiversity and Conservation, 15, 2515-2545.

Smith, R.M., Thompson, K., Hodgson, J.G., Warren, P.H. \& Gaston, K.J. (2006b) Urban domestic gardens (IX): composition and richness of the vascular plant flora, and implications for native biodiversity. Biological Conservation, 129, 312-322.

Speight, M.R., Hunter, M.D. \& Watt, A.D. (2008) The Ecology of Insects: Concepts and Applications, 2nd edn. Blackwell Scientific, Oxford, UK.

Steytler, N.S. \& Samways, M.J. (1995) Biotope selection by adult male dragonflies (Odonata) at an artificial lake created for insect conservation in South-Africa. Biological Conservation, 72, 381-386.

Strauss, B. \& Biedermann, R. (2006) Urban brownfields as temporary habitats: driving forces for the diversity of phytophagous insects. Ecography, 29, 928-940.

Suh, A.N. \& Samways, M.J. (2005) Significance of temporal changes when designing a reservoir for conservation of dragonfly diversity. Biodiversity and Conservation, 14, 165-178.

Talley, T.S., Fleishman, E., Holyoak, M., Murphy, D.D. \& Ballard, A. (2007) Rethinking a rare-species conservation strategy in an urban landscape: the case of the valley elderberry longhorn beetle. Biological Conservation, 135, 21-32.

Tommasi, D., Miro, A., Higo, H.A. \& Winston, M.L. (2004) Bee diversity and abundance in an urban setting. Canadian Entomologist, 136, 851-869.

Ulrich, R.S. (1986) Human responses to vegetation and landscapes. Landscape and Urban Planning, 13, 29-44.

Uzzell, D., Pol, E. \& Badenas, D. (2002) Place identification, social cohesion, and environmental sustainability. Environment and Behavior, 34, 26-53.

Valtonen, A., Saarinen, K. \& Jantunen, J. (2007) Intersection reservations as habitats for meadow butterflies and diurnal moths: guidelines for planning and management. Landscape and Urban Planning, 79, 201-209.

Villagran-Mella, R., Aguayo, M., Parra, L.E. \& Gonzalez, A. (2006) Relationship between habitat characteristics and insect assemblage structure in urban freshwater marshes from central-south Chile. Revista Chilena De Historia Natural, 79, 195-211.

Waite, T.A., Chhangani, A.K., Campbell, L.G., Rajpurohit, L.S. \& Mohnot, S.M. (2007) Sanctuary in the city: urban monkeys buffered against catastrophic die-off during ENSO-related drought. Ecohealth, 4, 278-286.

Wallace, J.B. \& Merritt, R.W. (1980) Filter-feeding ecology of aquatic insects. Annual Review of Entomology, 25, 103-132.

Whitmore, C., Crouch, T.E. \& Slotow, R.H. (2002) Conservation of biodiversity in urban environments: invertebrates on structurally enhanced road islands. African Entomology, 10, 113-126.

Wilson, E.O. (1987) The little things that run the world (the importance and conservation of invertebrates). Conservation Biology, 1, 344-346.

Wood, P.J., Greenwood, M.T., Barker, S.A. \& Gunn, J. (2001) The effects of amenity management for angling on the conservation value of aquatic invertebrate communities in old industrial ponds. Biological Conservation, 102, 17-29.

Accepted 16 June 2008

First published online 28 July 2008

Editor: Calvin Dytham

Associate Editor: Raphael Didham 